\title{
Changes in seagrass polychaete assemblages after invasion by Caulerpa racemosa var. cylindracea (Chlorophyta: Caulerpales): community structure, trophic guilds and taxonomic distinctness
}

\author{
ANTONIO BOX $^{1}$, DANIEL MARTIN ${ }^{2}$ and SALUD DEUDERO ${ }^{1}$ \\ ${ }^{1}$ Laboratorio de Biología Marina, Universidad de las Islas Baleares (UIB), Ctra Valldemossa Km 7.5, 07122 Mallorca, \\ Islas Baleares. Spain. E-mail: toni.box@uib.es \\ ${ }^{2}$ Centre d'Estudis Avançats de Blanes (CEAB), Consejo Superior de Investigaciones Científicas (CSIC), \\ Carrer d'accés a la cala Sant Francesc 14, 17300 Blanes, Girona, Catalunya, Spain.
}

\begin{abstract}
SUMMARY: A two-year study focusing on the associated polychaete assemblages revealed that the degradation of the Posidonia oceanica seagrass meadows, together with the colonisation of rhizomes by invasive Caulerpa racemosa in the Balearic Islands, have produced important changes in the ecosystem functioning, and have therefore affected the benthic faunal communities. The highest abundance and number of species occurred in $C$. racemosa from August to December. The species composition of the polychaete assemblage in $C$. racemosa is similar to that of $P$. oceanica but abundances of shared species differ between Caulerpa and Posidonia. Abundance, number of species and diversity were positively correlated with C. racemosa biomass. The spatial complexity provided by the network of $C$. racemosa fronds and stolons seemed to combine with that of the remaining seagrass mat to support a well developed polychaete assemblage. Although invaded meadows harboured significantly modified polychaete assemblages when compared with living $P$. oceanica meadows, the main impacts seem to be non-harmful (i.e. increased abundance and number of species) and mainly affect their seasonal patterns, which is a direct consequence of the corresponding biomass seasonality of $C$. racemosa.
\end{abstract}

Keywords: Posidonia oceanica, Caulerpa racemosa, Polychaeta, species diversity, trophic guilds, taxonomic distinctness, introduced species, Mediterranean.

RESUMEN: CAMBIOS EN LA COMUNIDAD DE POLIQUETOS ASOCIADOS A LA INVASIÓN DE CAULERPA RACEMOSA VAR. CYLINDRACEA (ChlOROPHYTA: CAUlERPALES): ESTRUCTURA DE COMUNIDAD, ESTRATEGIAS TRÓFICAS Y DISTINCIÓN TAXONÓMICA. - En las Islas Baleares, la degradación de las praderas de Posidonia oceanica junto con la colonización de los restos de rizoma por Caulerpa racemosa conllevan importantes cambios en el funcionamiento del ecosistema, los cuales afectan especialmente a las comunidades de invertebrados. El presente estudio muestra que, a lo largo de dos años, las mayores abundancias y diversidades de poliquetos en rizomas invadidos por C. racemosa se han encontrado en agosto y septiembre. La composición específica en dichos rizomas invadidos es muy similar a la propia de las praderas de $P$. oceanica, si bien algunas de especies coincidentes difieren claramente en abundancia. La biomasa de C. racemosa muestra una correlación positiva con la abundancia, número de especies y diversidad de poliquetos. La complejidad espacial asociada a los frondes y estolones de $C$. racemosa se combinan con los restos de rizoma, generando un hábitat capaz de mantener una comunidad de poliquetos bien estructurada. Sin embargo, a pesar de las diferencias encontradas entre las respectivas comunidades de poliquetos, el impacto de la invasión parece no ser negativo (e.g. aumentan la abundancia de algunas especies y la diversidad específica) y afecta principalmente a su pauta estacional, siendo consecuencia directa de la estacionalidad del ciclo vegetativo de $C$. racemosa.

Palabras clave: Posidonia oceanica, Caulerpa racemosa, poliquetos, diversidad de especies, estrategias tróficas, distinción taxonómica, especies introducidas, Mediterráneo. 


\section{INTRODUCTION}

The presence of alien species in the Mediterranean, currently about 662 (Gollasch, 2006), is an increasing problem that still needs to be studied to clarify its consequences. Invasive species are considered a serious threat to natural ecosystems (Mack et al., 2000), as well as one of the major drivers of biodiversity loss (Sakai et al., 2001). Invaders could be highly competitive and their interaction with native species may cause a global decrease in biodiversity (Bax et al., 2003). Negative effects of invasive species on the local biota have been recently reported, especially for macroalgal communities (Piazzi and Cinelli, 2000; Meinesz et al., 2001; Balata et al., 2004; Meinesz, 2004). In the Mediterranean Sea, 84 introduced macrophytes have been reported to date (Boudouresque and Verlaque, 2002), and two of them belong to the green algae genus Caulerpa: C. taxifolia and C. racemosa (Ceccherelli and Sechi, 2002). Their presence induces drastic changes in faunistic composition and abundance of the affected systems, and thus they have become a serious problem in the western Mediterranean (Pandolfo and Chemello, 1995; Bellan-Santini et al., 1996; Argyrou et al., 1999; Buia et al., 2001). Caulerpa species produce anti-herbivorous secondary metabolites (Amade and Lemee, 1998; Jung et al., 2002), the main one being caulerpenyne, which negatively affect grazing organisms (Boudouresque et al., 1996; ParentMassin et al., 1996; Amade and Lemee, 1998; Pesando et al., 1998; Sureda et al., 2006; Sureda et $a l ., 2008)$ and chemically change the environmental conditions of the habitat (Amade and Lemee, 1998; Sureda et al., 2006).

Posidonia oceanica (L.) Delile meadows are among the most important Mediterranean ecosystems, with an estimated extension of between 2.5 and 5.5 million hectares (Buia et al., 2001). Posidonia beds are characterised by having a foliar canopy and a root-rhizome layer, and this structure strongly influences the associated fauna. Even dead (i.e. after losing the foliar structures) Posidonia beds still support a rich macrofauna in terms of the number of species and diversity (Borg et al., 2006). However, the particular characteristics of $P$. oceanica meadows make them highly sensitive to competitors, such as the invasive species of the genus Caulerpa (Ceccherelli et al., 2002), which leads to a large decrease in shoot density (Molenaar et al., 2009).
Local species being replaced by invaders is nowadays a worldwide phenomenon (Montefalcone et al., 2007), and the Mediterranean Posidonia meadows are no exception. Our study focuses particularly on the invading Caulerpa racemosa, which has already been reported in 12 Mediterranean countries: Italy, Greece, Albania, Cyprus, France, Turkey, Malta, Spain, Tunisia, Croatia, Algeria and Libya (Klein and Verlaque, 2008). Caulerpa racemosa spreads in sheltered and exposed areas, colonising all kinds of substrates from 0 to $70 \mathrm{~m}$ depth (Argyrou et al., 1999; Piazzi and Cinelli, 1999; Zuljevic et al., 2003). Introduced species often become more invasive in impacted ecosystems. For instance, the brown alga Sargassum muticum substitutes Zostera marina in damaged beds of the French Atlantic coast (Givernaud et al., 1991), and the green alga Enteromorpha radiata, which spreads in deteriorated mixed beds of Zostera noltii and Z. marina on the coasts of Great Britain (Der Hartog, 1994). In particular, regressive Posidonia oceanica meadows are more prone to being invaded by $C$. racemosa var. cylindracea than healthy ones (Ceccherelli et al., 2000).

The invertebrate assemblages, including those associated with seagrass beds, may also be affected by the presence of invasive species, which may either enhance (Argyrou et al., 1999; Antoniadou and Chintiroglou, 2007) or decrease (Galil and Zenetos, 2002; Zenetos et al., 2003; Streftaris and Zenetos, 2006) diversity. Among benthic invertebrates, the polychaetes are considered to be excellent descriptors of the structure of faunal assemblages, including those in association with seagrasses (Gambi et al., 1998; Brito et al., 2005). Although Posidonia oceanica beds lack exclusive polychaete species, the structure of their assemblages is very characteristic and tends to differ among the leaf stratum and the rhizomes and "matte". Polychaete abundance and diversity tend to be lower in the leaf stratum whilst, in general, there are no dominant species in the matte, where there is a higher richness of relatively less abundant species (Gambi et al., 1995).

In turn, diversity and abundance of soft-bottom polychaetes have been reported to increase in the presence of Caulerpa racemosa (Argyrou et al., 1999). Therefore, our study aimed to describe the structure (both in terms of species and trophic diversity) and seasonal patterns of the polychaete assemblages associated with dead Posidonia meadows invaded by C. racemosa, and to compare them with those associated with living Posidonia meadows. 


\section{MATERIALS AND METHODS}

\section{Study area}

The study was carried out at Mallorca Island (Balearic Islands, Western Mediterranean), where Caulerpa racemosa var. cylindracea has overgrown dead Posidonia meadows forming patches surrounded by bare sand and living seagrass meadows. Samples of C. racemosa var. cylindracea (hereafter called Caulerpa mats) were collected in the proximities of Portals Vells, southwest Mallorca $\left(\mathrm{N} 39^{\circ} 28.321^{\prime} / \mathrm{E} 2^{\circ} 31.320^{\prime}, 5\right.$ to $8 \mathrm{~m}$ deep). For the comparisons, samples of living Posidonia oceanica (hereafter called Posidonia meadows) were collected in the proximities of Cala D'Or, southeast Mallorca (N39 $22.164^{\prime} / \mathrm{E}^{\circ}{ }^{\circ} 13.887^{\prime}$ and $\mathrm{N} 39^{\circ} 22.028^{\prime}, 5$ to $8 \mathrm{~m}$ deep), which was not invaded by Caulerpa.

\section{Sampling}

From February 2004 to February 2005, Caulerpa mats and Posidonia meadows were sampled bimonthly in three sampling areas per meadow (each separated by $100 \mathrm{~m}$ ). According to Sanchez-Moyano et al. (2001), we used a $20 \times 20 \mathrm{~cm}$ frame inserted 5 $\mathrm{cm}$ into the sediment to collect samples, which were then placed in a plastic mesh bag $(0.5 \mathrm{~mm}$ pore size $)$, fixed in a $4 \%$ formaldehyde-seawater solution and preserved in $70 \%$ ethanol prior to being sorted in the laboratory. Caulerpa racemosa was sorted and dryweighted $\left(24 \mathrm{~h}\right.$ at $\left.60^{\circ} \mathrm{C}\right)$, as well as the rhizomes, roots and sheaths of the dead Posidonia mat. For the living Posidonia meadows, leaves were also sorted and dry-weighted $\left(24 \mathrm{~h}\right.$ at $\left.60^{\circ} \mathrm{C}\right)$. All biomasses were expressed as percentages.

The polychaete specimens were sorted under a stereomicroscope, identified at the lowest possible taxonomic level, and grouped into trophic guilds: carnivorous, herbivorous, omnivorous, deposit feeders and filter feeders (according to Fauchald and Jumars, 1979; Gambi et al., 1995; Martin et al., 2000; Antoniadou and Chintiroglou, 2006).

In parallel, three additional corers per meadow and sampling date (inserted $5 \mathrm{~cm}$ into the sediment) were collected to analyse the granulometry of the surrounding sediments. The sediment was dried for $24 \mathrm{~h}$ (after being treated with $\mathrm{H}_{2} \mathrm{O}_{2}$ for $24 \mathrm{~h}$ ) and the grain size fractions were estimated following the scale established by Wentworth (1972).

\section{Data analysis}

Five different categories of substrata were considered for analysing the polychaete assemblages associated with Caulerpa mats: Caulerpa networks and Posidonia rhizomes, sheaths, dead leaves and roots. Living leaves were also included in the case of Posidonia meadows. The observed differences in the polychaete assemblages were tested by two-way analysis of variance (two-way ANOVA) including meadow type and time as factors. Principal component analysis (PCA) was used to analyse the influence of the structural parameters (i.e. Posidonia fractions and Caulerpa network biomasses, grain size fractions) on sample seasonal trends.

For statistical purposes (except for TAXDTEST, PRIMER 6.0), the species of Paraonidae, Capitellidae, Sabellidae and Maldanidae were pooled at family level due to the misidentification of several individuals. A species was considered as dominant when its abundance was more that $1 \%$ of the total.

The structure of the polychaete assemblages was analysed using PRIMER 6.0 software. A cluster analysis was performed on a resemblance matrix (Bray-Curtis index) based on a fourth-root transformed abundance per sample matrix (replicate samples pooled by meadow and sampling date). No reduction in species was applied. The multidimensional scaling (MDS) routine was used for a two-dimensional representation. The differences between cluster groups were assessed by the ANOSIM routine. The species responsible for the observed differences were identified by means of the SIMPER routine. The DIVERSE routine was used to calculate the density, number of species per sample, diversity and evenness for the obtained cluster groups.

The relationships between $C$. racemosa biomass, polychaete assemblage descriptors and trophic groups were assessed by pairwise Pearson correlations. Changes in trophic guilds were tested by one-way ANOVA (meadow as factor). The seasonal trends of the assemblages were analysed by two-way ANOVA (meadow and time as factors) based on the polychaete species with higher resemblance contributions (SIMPER routine).

In order to compare the species composition and seasonality of the polychaete assemblages inhabiting Posidonia meadows and Caulerpa mats, we used the taxonomic distinctness (AvTD, $\Delta^{+}$) and its variation $\left(\right.$ VarTD $\Delta^{+}$) obtained with the TAXDTEST routine of the PRIMER 6.0 software (Clarke and Warwick, 
2001). This allowed us to calculate the average taxonomic relatedness for samples or treatments, as well as compare this to the range of values calculated by repeatedly taking random samples of the same size (as number of species) from an appropriate master list (Clarke and Warwick, 2001; Warwick and Light, 2002; Smith, 2008). In our case, this list was based on the exhaustive inventory of Posidonia invertebrates from the Balearic Islands (18 stations, 0 to $35 \mathrm{~m}$ deep) made by Ballesteros et al. (1987), complemented with the species from Cala d'Or meadows to avoid species omissions (Smith, 2008). The master list finally included 140 polychaete species. TAXDTEST was also applied to data pooled as Posidonia meadow, and low- and high-Caulerpa biomass periods (samples with low/null (less than 5 $\mathrm{g} / \mathrm{m}^{2} \mathrm{DW}$ ) or high biomass respectively).

\section{RESULTS}

\section{Sample characterisation}

Sheaths were the dominant fraction both in Caulerpa mats and Posidonia meadows, followed by roots and living leaves respectively (Fig. 1a).

Fine sand was the dominant grain size both in Caulerpa mats and Posidonia meadows, but in Caulerpa mats there was a higher contribution of large grain size fractions (Fig. 1b). The maximum algal biomasses in Caulerpa mats occurred from August to December, and were highly influenced by the warm conditions in the last months of 2004 (Fig. 2).

In the PCA (Fig. 3), the first axis (eigenvalue $10.4,74.1 \%$ of the explained variance) was mostly related to Caulerpa (eigenvector 0.607) and biomasses of living Posidonia leaves (eigenvector -0.602). The second axis (eigenvalue 1.94, 13.8\% of the explained variance) was mostly related to the living Posidonia leaf (eigenvector 0.683) and sheath (eigenvector -0.584) biomasses. Caulerpa mats and Posidonia meadows are clearly separated along the first axis (positive and negative sectors respectively), and there is a distinction between little and highly invaded sampling periods (the later with more positive eigenvalues). In turn, the second axis distinguishes the Posidonia meadows with low leaf biomass in autumn and winter (positive eigenvalues) from those with high leaf biomass in spring and summer (negative eigenvalues) (Fig. 3).
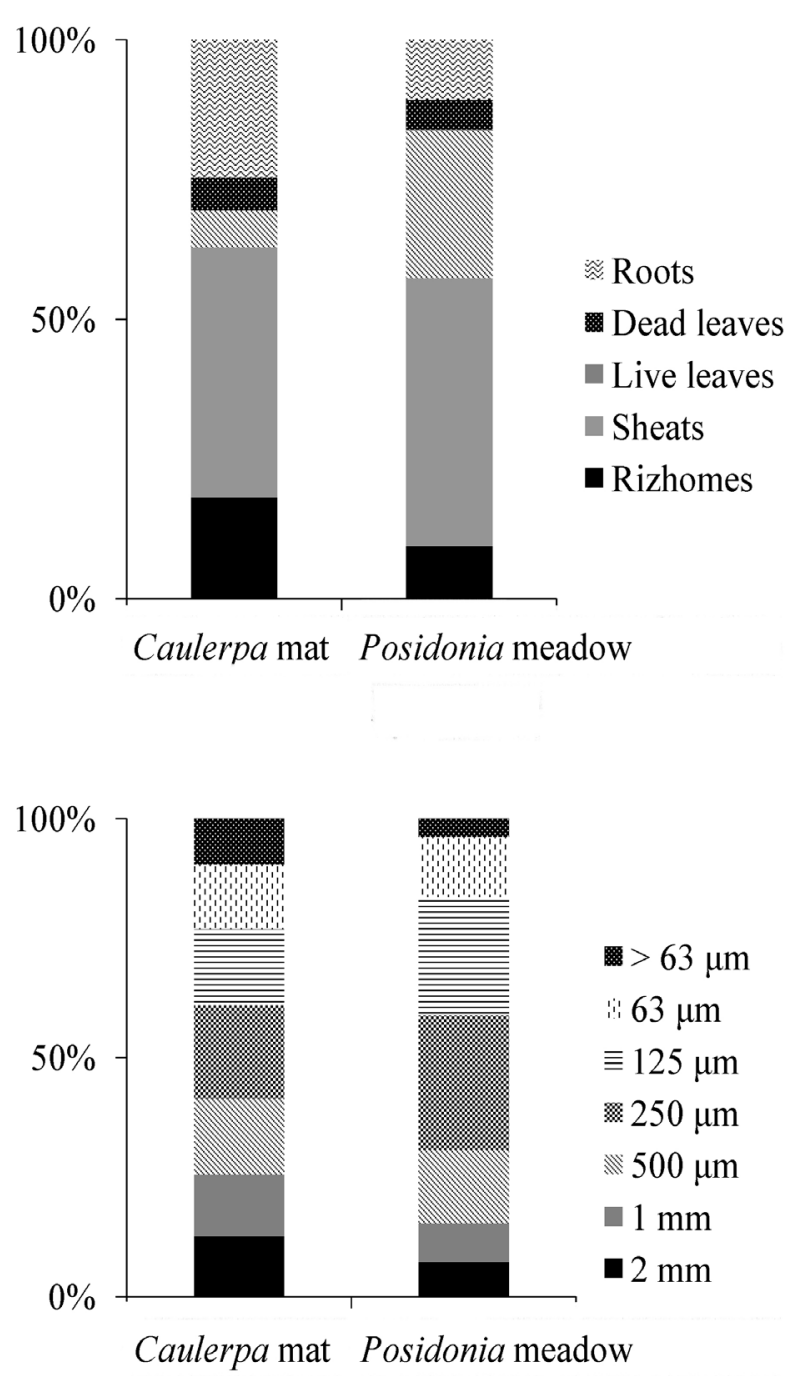

FIG. 1. - Caulerpa mat and Posidonia meadow annual means of: A, Biomass of the Posidonia fractions (percentage in weight); B, granulometry (Wentworth scale).

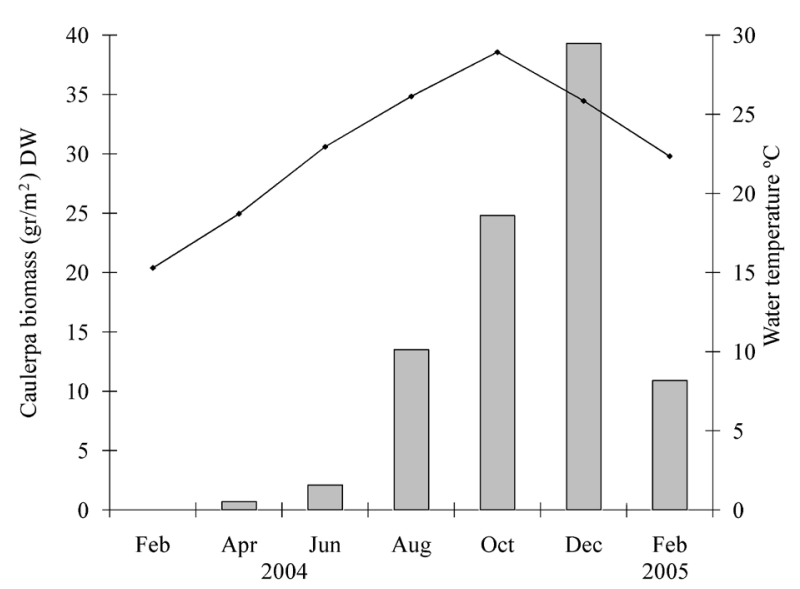

FIG. 2. - Seasonal patterns in Caulerpa racemosa biomass and water temperature. 


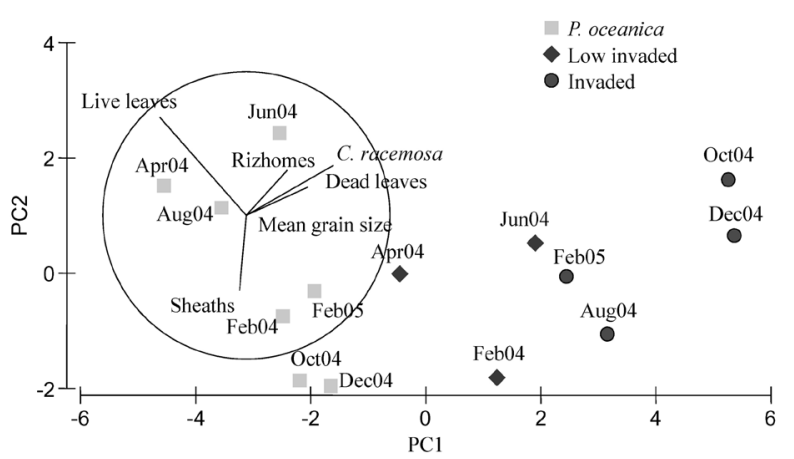

FIG. 3. - Principal component analysis of the seasonal Posidonia meadows and Caulerpa mats related to the measured structural parameters. Low Caulerpa biomass samples are those with biomasses lower than $5 \mathrm{~g} / \mathrm{m}^{2} \mathrm{DW}$. Variable vector is in the circle on the left of the plot.

\section{Faunistic composition}

1863 polychaetes from 43 taxa were identified in Caulerpa mats, with Nereididae and Sigalionidae being the most abundant throughout the year. The species richness was high and 25 species were dominant through the year. Neanthes agulhana, Pelogenia arenosa, Polyophthalmus pictus and Lumbrineris latreilli were the most abundant (Table 1). Neanthes agulhana was present in all sampled periods, while $P$. arenosa, P. pictus, Arabella iricolor and Sthenelais boa showed frequencies over $70 \%$ (Table 1). The internal similarity of the assemblages from Caulerpa mats was $32.57 \%$ and $N$. agulhana, $P$. arenosa, $P$. pictus, Capitellidae, A. iricolor, L. latreilli, S. boa, Harmothoe spinifera, Pholoe inornata, Pontogenia chrysocoma and Syllis garciai accounted for more than $80 \%$.

1475 polychaetes from 44 taxa were identified in Posidonia meadows, with Eunicidae and Nereididae being the most abundant throughout the year. The species richness was high, with 29 dominant species. Nematonereis hebes, Aponuphis bilineata and Neanthes agulhana were the most abundant (Table 2). Lumbrineris gracilis, A. bilineata and N. agulhana showed frequencies over $70 \%$ (Table 2). The internal similarity of the assemblages from Posidonia meadows was $25.01 \%$, and Capitellidae, A. bilineata, L. gracilis, N. agulhana, N. hebes, Maldanidae, Polyophthalmus pictus, Eunice vittata, Lumbrineris latreilli and Terebellidae were the taxa that made the highest contributions ( $\geq 80 \%)$ and accounted for more than $80 \%$.

The structure of the polychaete assemblages showed seasonal differences (Fig. 4). At 60\% similarity, Group 1 includes all Caulerpa mats with higher algal biomass (i.e. August, October and December). Then, at $40 \%$ similarity, all remaining Caulerpa mats (except February 2005) joined Group 1 successively, while the February 2005 mat was clustered with the October 2004 Posidonia meadow (Group 2). Group 3 included late winter, spring and early summer Posidonia meadows from 2004, while both the 2004 and 2005 winter Posidonia meadows formed Group 4. Finally, the single summer Posidonia meadow remained isolated in Group 5.

There were significant differences among all cluster groups (ANOSIM, global $R=0.769$, number of used permutations $=20000$, significance level $=$ $0.1 \%$ ) (Table 3). The dissimilarity between Group 1 and all other groups were mainly caused by Polyophthalmus pictus, Neanthes agulhana, Lumbrineris latreilli and Capitellidae (Table 3).

In Caulerpa mats, the maximum densities and highest number of species occurred in October, while the maximum diversities and evenness corresponded to August/December and August respectively. Ac-
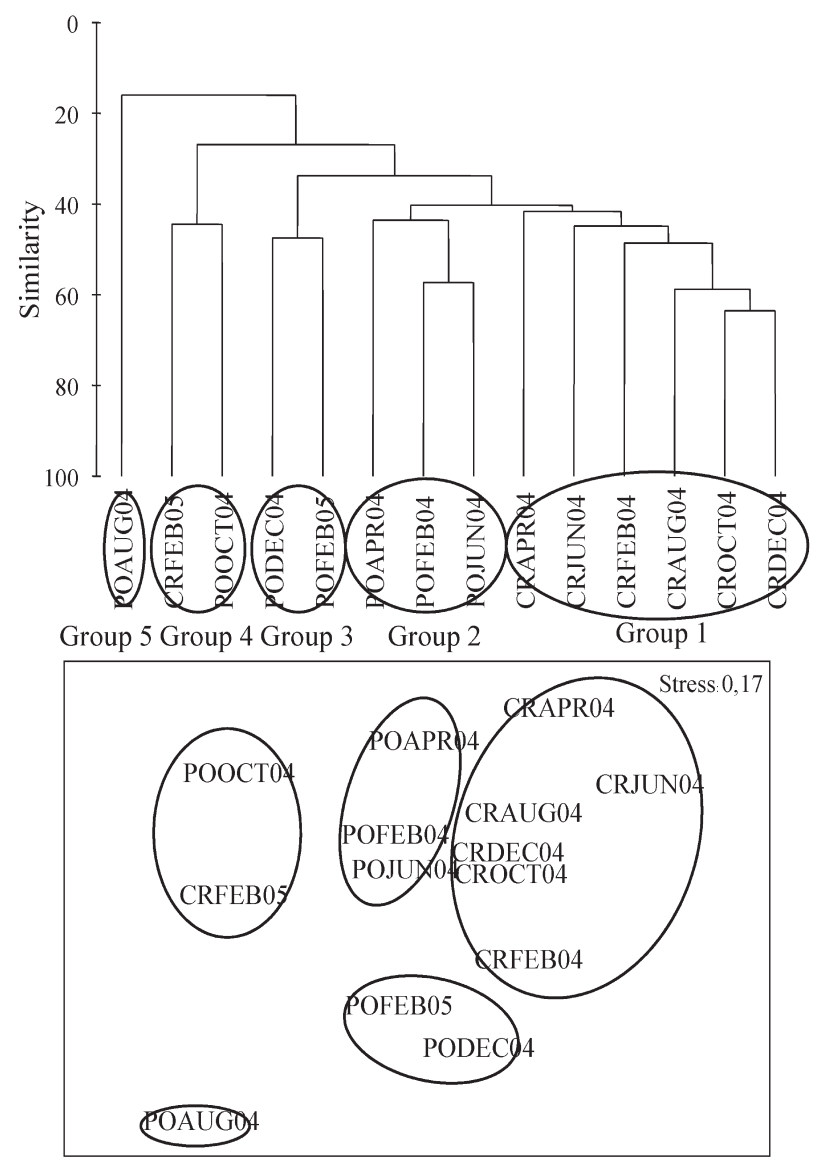

FIG. 4. - Cluster and MDS representation of polychaete assemblages from Caulerpa mats and Posidonia meadows. 


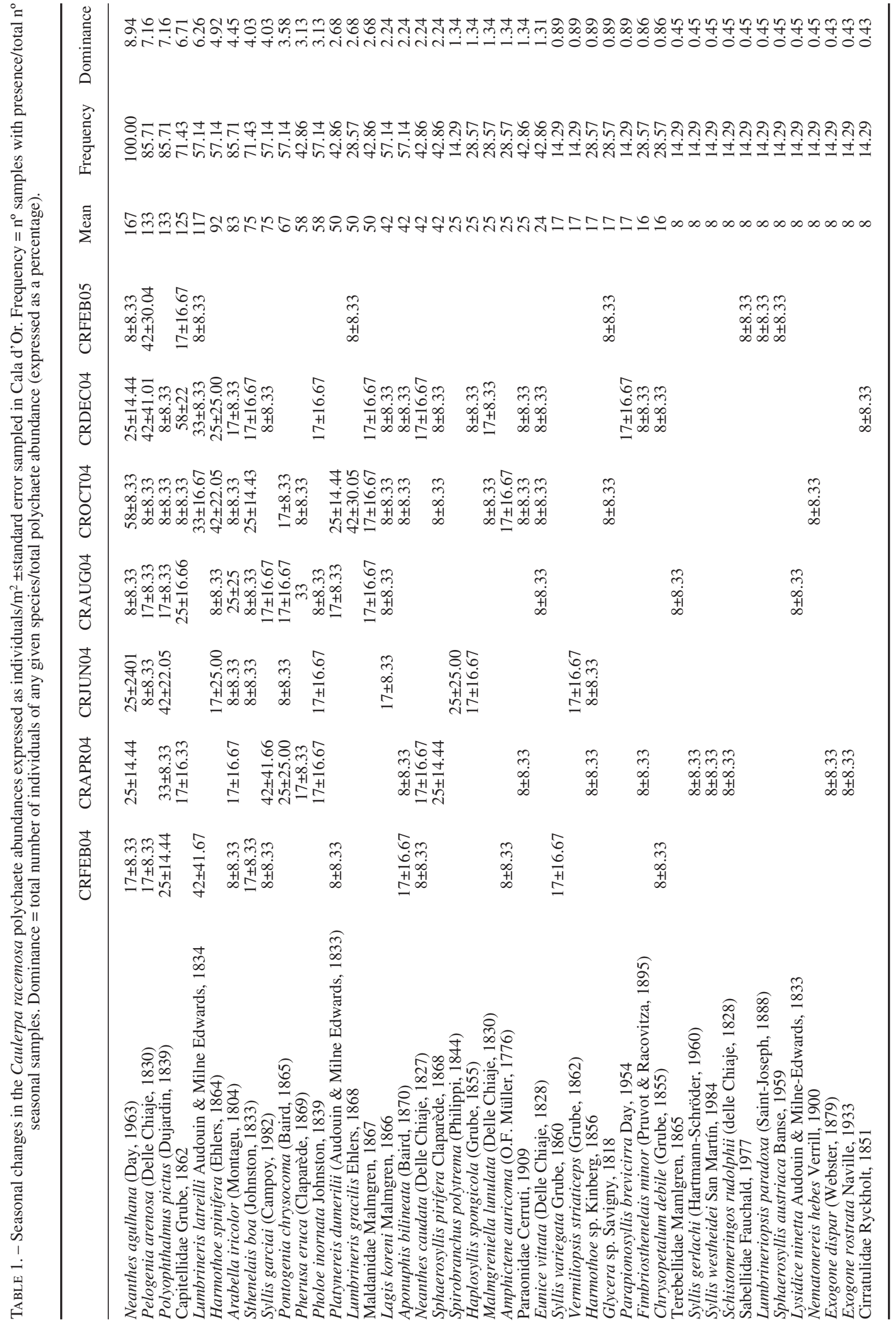

SCI. MAR., 74(2), June 2010, 317-329. ISSN 0214-8358 doi: 10.3989/scimar.2010.74n2317 


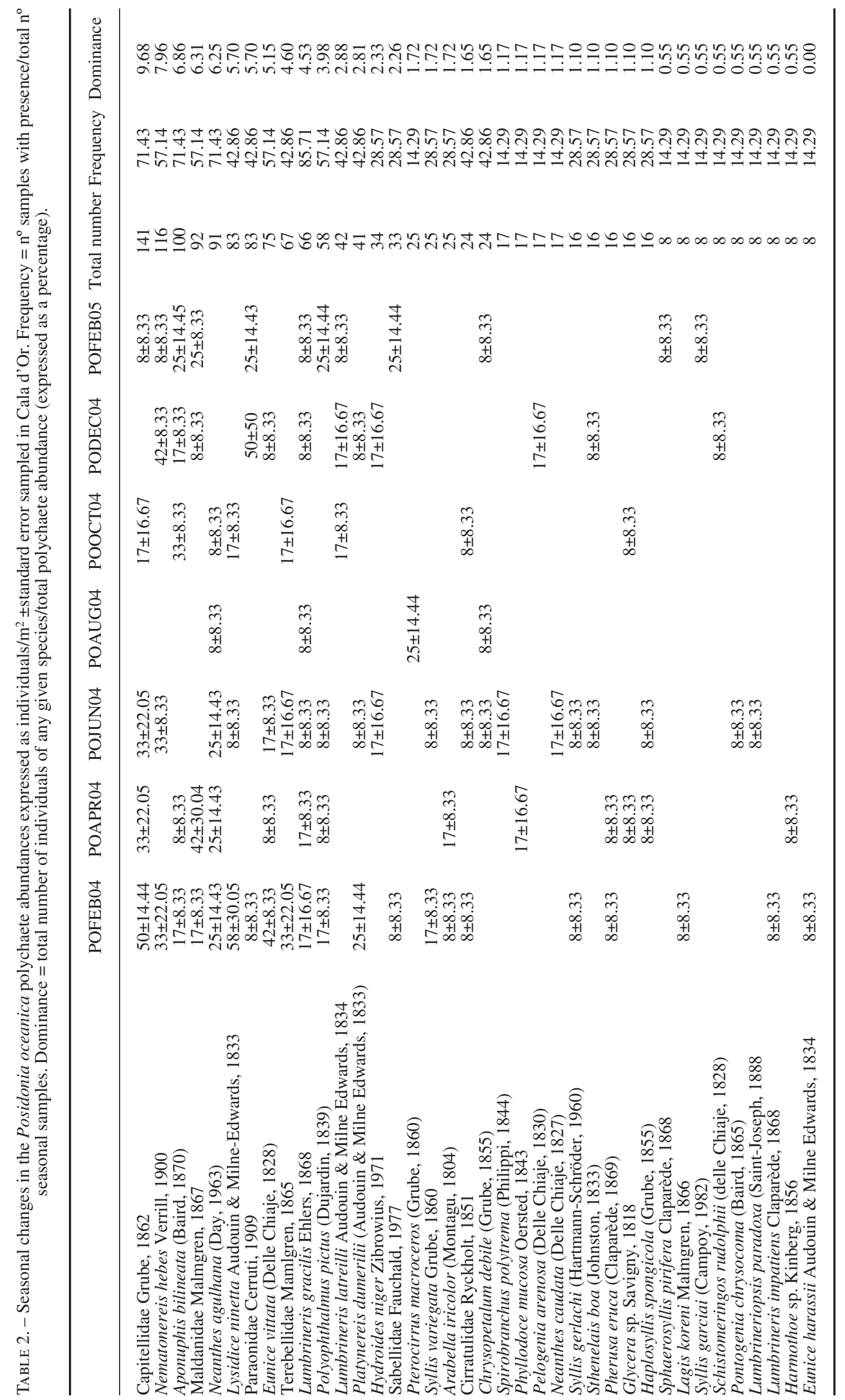


TABLE 3. - ANOSIM and SIMPER analysis between groups established after Cluster analysis.

\begin{tabular}{|c|c|c|c|c|}
\hline \multirow{2}{*}{ GROUPS } & \multicolumn{2}{|c|}{ ANOSIM } & \multirow{2}{*}{$\begin{array}{c}\text { SIMPER } \\
\text { Average Dissimilarity }\end{array}$} & \multirow{2}{*}{ Species most contributing to dissimilarity (up to $60 \%$ ) } \\
\hline & R statistic & Sig level\% & & \\
\hline Group 1-2 & 0.432 & 1.2 & 67.81 & $\begin{array}{l}\text { Capitellidae, } N \text {. hebes, Maldanidae, } L \text {. ninetta, } L \text {. latreilli, E. vittata, } \\
\text { L. gracilis, } P \text {. arenosa, Terebellidae, } P \text {. pictus, } H \text {. spinifera, } \\
\text { S. garciai. } P \text {. dumerilii, S. boa, P. eruca }\end{array}$ \\
\hline Group 1-3 & 0.646 & 3.6 & 76.35 & $\begin{array}{l}\text { Paraonidae, } N . \text { agulhana, } N \text {. hebes, } L . \text { latreilli, } P \text {. pictus, } \\
\text { Capitellidae, A. bilineata, } H . \text { spinifera, A. iricolor, Maldanidae, } \\
\text { Sabellidae, P. arenosa, L. gracilis, S. garciai. }\end{array}$ \\
\hline Group 1-4 & 1 & 3.6 & 81.21 & $\begin{array}{l}\text { P. pictus, } P . \text { arenosa, L. latreilli, A. bilineata, N. agulhana, } \\
\text { Capitellidae, A. iricolor, H. spinifera, S. garciai, S. boa, } \\
\text { P. chrysocoma, P. eruca, P. inornata, L. gracilis. }\end{array}$ \\
\hline Group 1-5 & 1 & 14.3 & 92.50 & $\begin{array}{l}\text { P. macroceros, } P \text {. pictus, L. latreilli, } N \text {. agulhana, Capitellidae, } \\
\text { P. arenosa, A. iricolor, H. spinifera, S. garciai, S. boa, L. gracilis, } \\
\text { P. chrysocoma. }\end{array}$ \\
\hline Group 2-3 & 0.667 & 10 & 73.74 & $\begin{array}{l}\text { Paraonidae, Capitellidae, N. agulhana, N. hebes, L. ninetta, } \\
\text { Maldanidae, E. vittata, Terebellidae, A. bilineata, Sabellidae, } \\
\text { P. pictus. }\end{array}$ \\
\hline Group 2-4 & 0.917 & 10 & 75.54 & $\begin{array}{l}\text { Maldanidae, } P \text {. arenosa, Capitellidae, } N \text {. hebes, E. vittata, } L \text {. ninetta, } \\
N \text {. agulhana, A. bilineata, Terebellidae, L. latreilli, } P \text {. pictus. }\end{array}$ \\
\hline Group 2-5 & 1 & 25 & 88.23 & $\begin{array}{l}\text { Capitellidae, } P \text {. macroceros, Maldanidae, } N \text {. hebes E. vittata, } \\
N \text {. agulhana, L. ninetta, Terebellidae, } P \text {. pictus }\end{array}$ \\
\hline Group 3-4 & 1 & 33.3 & 77.56 & $\begin{array}{l}\text { Paraonidae, } N \text {. hebes, } P \text {. arenosa, Maldanidae, A. bilineata, } \\
P \text {. pictus, Sabellidae, Capitellidae. }\end{array}$ \\
\hline Group 3-5 & 1 & 33.3 & 89.63 & $\begin{array}{l}\text { Paraonidae, } P . \text { macroceros, } N \text {. hebes, A. bilineata, Maldanidae, } \\
\text { P. pictus. }\end{array}$ \\
\hline Group 4-5 & 1 & 33.3 & 85.24 & P. macroceros, $P$. arenosa, Capitellidae, $A$. bilineata, L. latreilli \\
\hline
\end{tabular}

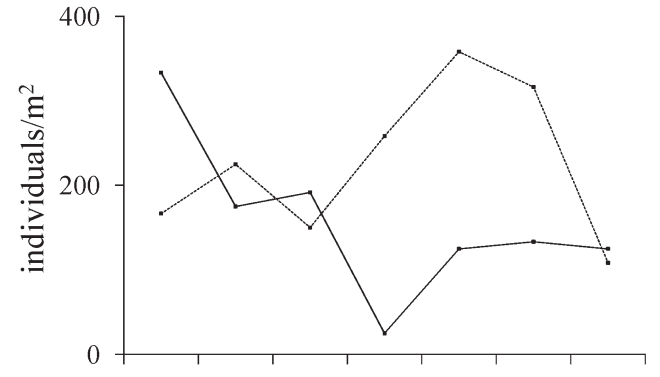

Feb Apr Jun Aug Oct Dec Feb

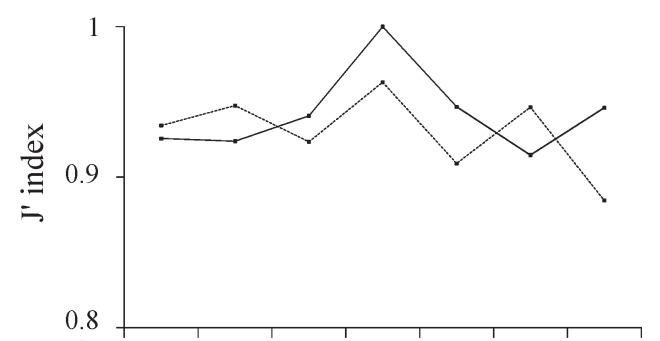

Feb Apr Jun Aug Oct Dec Feb

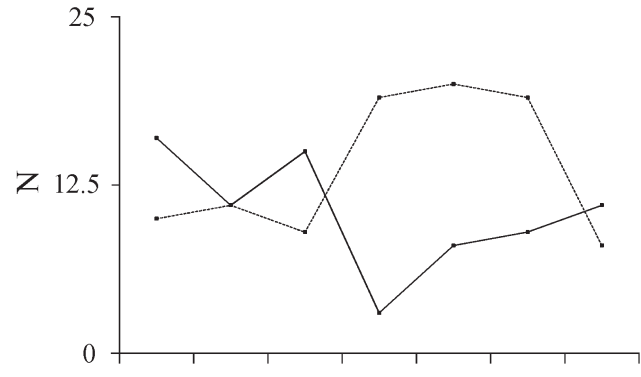

Feb Apr Jun Aug Oct Dec Feb

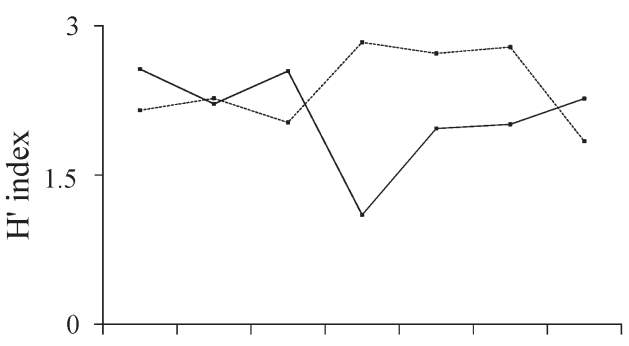

Feb Apr Jun Aug Oct Dec Feb

$\rightarrow$ C. racemosa $\rightarrow$. . oceanica

FIG. 5. - Total Polychaeta abundances per square meter and number of species (N), Jaccard index (J) and Shannon-Wiener index (H') in Posidonia meadows and Caulerpa mats with seasonal changes (February 04 to February 05). 
TABLE 4. - Significance of the differences in abundance between habitats (Caulerpa mats and Posidonia meadows) and sampling dates tested by two-way ANOVA. Species selected according to the SIMPER percentages of similarity. ${ }^{* * * *}: p<0.001,{ }^{* *}: p<0.01 ;{ }^{*}: p<0.05$.

\begin{tabular}{|c|c|c|c|c|c|c|c|}
\hline & & Arabella iricolor & Paraonidae & Capitellidae & Cirratulidae & Chrysopetalum debile & Eunice vittata \\
\hline Source of variation & Df & MS & MS & MS & MS & MS & MS \\
\hline Habitat & 1 & 2,526 & 0.256 & 0.436 & $2.411^{*}$ & 0.023 & 0.471 \\
\hline Date & 9 & 0.895 & 0.774 & 0.995 & 0.441 & 0.222 & 1.208 \\
\hline Habitat*Date & 9 & 0.589 & 0.723 & $4.776^{* * *}$ & 0.677 & 0.556 & 1.838 \\
\hline \multirow[t]{2}{*}{ Residual } & 40 & 0.846 & 0.640 & 1.081 & 0.553 & 0.500 & 0.806 \\
\hline & & $\begin{array}{l}\text { Harmothoe } \\
\text { spinifera }\end{array}$ & $\begin{array}{l}\text { Aponuphis } \\
\text { bilineata }\end{array}$ & $\begin{array}{l}\text { Lumbrineris } \\
\text { gracilis }\end{array}$ & $\begin{array}{l}\text { Lumbrineris } \\
\quad \text { latreilli }\end{array}$ & Lysidice ninetta & Maldanidae \\
\hline Habitat & 1 & $2.824^{*}$ & 0.688 & 0.433 & $7.428^{* *}$ & $3.775^{*}$ & 2.113 \\
\hline Date & 9 & 0.566 & 1.507 & 0.792 & $2.653^{* *}$ & 0.725 & 1.068 \\
\hline Habitat*Date & 9 & 0.875 & 2.036 & $2.772^{* * *}$ & 1.231 & 1.012 & $1.882^{*}$ \\
\hline \multirow[t]{2}{*}{ Residual } & 40 & 0.678 & 1.128 & 0.854 & 1.547 & 0.573 & 0.822 \\
\hline & & $\begin{array}{l}\text { Neanthes } \\
\text { agulhana }\end{array}$ & Nematonereis hebes & Lagis koreni & Pelogenia arenosa & a Pholoe inornata & $\begin{array}{l}\text { Platynereis } \\
\text { dumerilii }\end{array}$ \\
\hline Habitat & 1 & $7.546^{*}$ & $5.179^{* *}$ & $2.083^{*}$ & $12.198^{* * *}$ & $6.117^{* *}$ & 0.055 \\
\hline Date & 9 & 1.973 & $1.729^{* *}$ & 0.380 & 0.767 & 0.361 & 0.926 \\
\hline Habitat*Date & 9 & 1.566 & $2.198^{* * * *}$ & 0.601 & 0.694 & 0.361 & 1.348 \\
\hline \multirow[t]{2}{*}{ Residual } & 40 & 1.232 & 0.457 & 0.500 & 0.990 & 0.687 & 0.739 \\
\hline & & $\begin{array}{l}\text { Polyophthalmus } \\
\text { pictus }\end{array}$ & $\begin{array}{l}\text { Pontogenia } \\
\text { chrysocoma }\end{array}$ & Sthenelais boa & Syllis garciai & Terebellidae & \\
\hline Habitat & 1 & $6.300^{*}$ & 0.333 & 3.390 & $5.851^{* * * *}$ & $4.169^{*}$ & \\
\hline Date & 9 & 1.738 & $1.496^{*}$ & $0.816^{*}$ & $2.375^{* *}$ & 1.394 & \\
\hline Habitat*Date & 9 & 1.419 & $1.892^{*}$ & 0.626 & $1.183^{* *}$ & 0.742 & \\
\hline Residual & 40 & 1.006 & 0.652 & 0.720 & 0.649 & 0.990 & \\
\hline
\end{tabular}

cordingly, Caulerpa biomass was positively correlated with density, number of species and diversity $(\mathrm{r}=0.839, \mathrm{r}=0.907$ and $\mathrm{r}=0.868 ; \mathrm{p}=0.05)$. Conversely, in Posidonia meadows, maximum densities, number of species and diversity occurred in February 2004, while maximum evenness was observed in August (Fig. 5). No significant correlations were found between any polychaete descriptors and the biomass of the different Posidonia fractions in Caulerpa mats and Posidonia meadows.

The analysis of the main species in Caulerpa mats and Posidonia meadows shows that there were significant differences in the abundances of several polychaete species, such as Harmothoe spinifera, Lumbrineris latreilli, Lysidice ninetta, Neanthes agulhana, Pelogenia arenosa, among others (Table 4)

\section{Trophic guilds}

No significant seasonal differences for the different trophic guilds were found either in Caulerpa mats or Posidonia meadows, the main guilds being (according to their abundance) deposit feeders, carnivores and omnivores. In both types of samples, herbivores and filter feeders were the least abundant guilds.
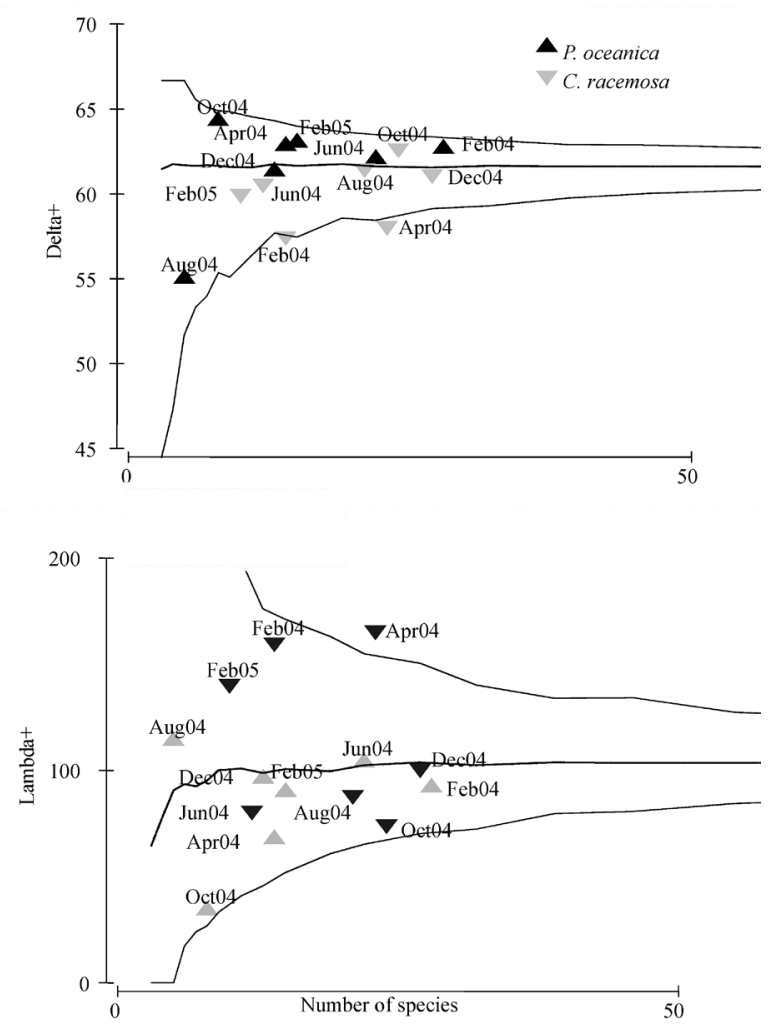

FIG. 6. - Confidence funnels (mean and 95\% probability intervals) of the average taxonomic distinctness $\left(\Delta^{+}\right)$and its variation $\left(\Lambda^{+}\right)$ generated from the master list showing the range of values displayed by the seasonal Caulerpa mats and Posidonia meadows 

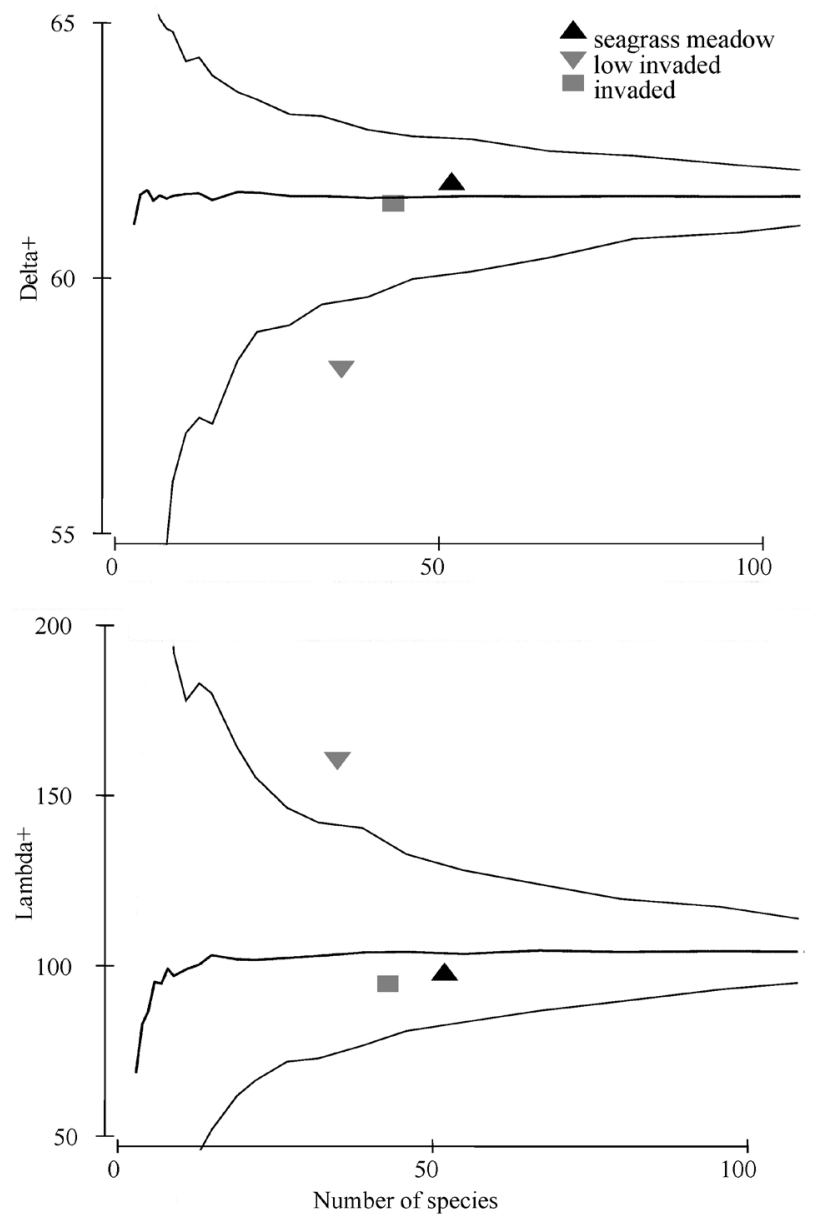

FIG. 7. - Confidence funnels (mean and $95 \%$ probability intervals) of the average taxonomic distinctness $\left(\Delta^{+}\right)$and its variation $\left(\Lambda^{+}\right)$ generated from the master list showing the relative position of the Posidonia meadows, high Caulerpa biomass and low Caulerpa biomass.

\section{Taxonomic distinctness}

Polychaete species composition in both Caulerpa mats and Posidonia meadows was similar, and thus when their seasonal variability was compared with the Balearic Islands master list, both the average taxonomic distinctness and its variation were also similar, except for the April Caulerpa mats (average taxonomic distinctness $P=0.003$ and variation in taxonomic distinctness $P=0.022$ ) (Fig. 6). In turn, both the average taxonomic distinctness and its variation fell inside the $95 \%$ probability funnel for both the Posidonia meadows and the Caulerpa mats during the periods with the highest Caulerpa biomass $\left(\Delta^{+} P=0.83 \Lambda^{+} P=0.66\right.$ and $\Delta^{+} P=0.64 \Lambda^{+} P=0.59$, respectively), while the indices for the Caulerpa mats during the periods with low Caulerpa biomass periods fell outside the $95 \%$ confidence interval $(P=$ 0.008 and $P=0.006$ respectively) (Fig. 7).

\section{DISCUSSION}

Polychaete assemblages associated with the invasive Caulerpa racemosa spreading along the western Mediterranean appear to have characteristic patterns of abundance, diversity and seasonal dynamics. The most influencing factors are the loss of Posidonia oceanica aboveground structures (leaves and vertical sheaths) in mats invaded by $C$. racemosa, which changes the habitat structure (with the short fronds and complex stolon network of the algae), and the marked seasonal dynamics of the algal biomass. When compared to living $P$. oceanica meadows, the effects of the invasion were shown to be non-negative. In fact, the abundance and number of species of the polychaete assemblages tended to increase, as previously reported for soft-bottoms colonised by $C$. racemosa (Argyrou et al., 1999).

The species composition of the polychaete assemblages associated with Caulerpa mats did not show a clear differentiation between samples. In other words, the assemblages were very uniform, most of them also included common soft bottom species, as reported for living Posidonia meadows (Gambi et al., 1995; Gambi et al., 1998; Brito et al., 2005). In the study area, several of the most abundant species in Caulerpa mats also occurred in Posidonia meadows and viceversa (i.e. Pelogenia arenosa, Polyophthalmus pictus, Lumbrineris latreilli and Arabella iricolor, on one side, and Nematonereis hebes, Aponuphis bilineata, Lysidice ninetta and Eunice vittata on the other). In fact, the increase or decrease in abundances of coincident polychaete species seems to be a characteristic trend when living $P$. oceanica and dead mats invaded by C. racemosa are compared. However, only Neanthes agulhana was dominant in both habitats, although it was significantly more abundant in Caulerpa mats.

The most abundant family in Caulerpa mats (and the second most abundant in Posidonia meadows) was the Nereididae, as previously reported for seagrass systems (Gambi et al., 1998). In addition to Neanthes agulhana, nereidids were represented by the omnivorous species Neanthes caudata and Platynereis dumerilii. The second most abundant family in Caulerpa mats was the carnivorous Sigalionidae (also relatively less abundant in Posidonia mats). As a general trend, carnivorous species tended to increase their abundance in Caulerpa mats. We postulated that a major availability of preys in Caulerpa mats, i.e. other polychaetes (this paper) and molluscs 
(Box, 2008), could be responsible for this increased presence of carnivores, both polychaetes (this paper) and crustaceans (Box, 2008).

In turn, a characteristic trend of the polychaete assemblages harboured by Caulerpa mats was the particular seasonal dynamics, which showed the highest density, species richness and diversity during summer and autumn. This pattern clearly differs from that of the assemblages associated with Posidonia meadows, which were most dense and diverse in winter (Gambi et al., 1995). Our results demonstrate that these seasonal peaks were linked to maximums of Caulerpa biomass. Thus, we postulated that the increasing spatial complexity provided by a high biomass of their stolons and fronds (Longepierre et al., 2005) growing over the dead seagrass mat layer, increased the complexity of the habitat and enhanced the structuring of the polychaete assemblage. During summer and autumn, the invasive algae grew quickly and formed extensive mats of stolons, which trapped sediments to the extreme that the lower vegetation layers may be affected (Balata et al., 2004). The stolon/frond network was less complex in winter and spring and, correspondingly, low polychaete densities and diversities were found. The co-generic invasive Caulerpa taxifolia also develops a network of stolons on the substratum surface and has a rhizoid system that allows it to colonise virtually all substrates (Levi and Francour, 2004). As a result, specialised species such as the fish Mullus surmuletus underwent strong decreases in densities in the presence of $C$. taxifolia (Longepierre et al., 2005). Caulerpa racemosa also developed a similar complex network, and thus has similar effects on $M$. surmuletus and other benthicfeeder fish such as Spondyliosoma cantharus (Box personal observations). However, the sharp decrease in its biomass during winter may reduce the overall impact on the invaded communities.

The presence of Caulerpa racemosa seemed to cause a significant reduction in the density of several polychaetes that are characteristic of Posidonia meadows, such as the eunicids Nematonereis hebes and Lysidice ninetta, which were also among the major contributors to the dissimilarity among Caulerpa mats and Posidonia meadows in the SIMPER analysis. However, the reasons for this negative effect are not clear, as it is not possible to assess whether it has a trophic basis, these species feed at $P$. oceanica scales according to Gambi et al. $(2003,2005)$, or a chemical basis linked to the secondary metabolites produced by the algae that may either affect grazing directly or indirectly through inhibiting growth or death of P. oceanica (Raniello et al., 2007).

Moreover, the marked changes in the associated polychaete assemblages induced by the increasing Caulerpa racemosa biomass tended to be stable through time, as revealed by the high similarity of the samples collected in August, October and December (which strongly influence the observed seasonal patterns). In addition, minimum $C$. racemosa biomasses were observed during the coldest months (i.e. February 2004 and April 2005), in parallel with a reduction in the polychaete abundance and diversity in the Caulerpa mats. Posidonia meadows did not show a seasonal pattern, and the assemblage descriptors were more homogeneous and stable through the year and relatively higher in winter. Compared with a bare sandy bottom, the presence of meadows increases the amount of fine particles and organic matter (Brito et al., 2005), but this is also true when compared to the winter, less dense, Caulerpa mats in the study area. The polychaete assemblages in living Posidonia meadows were less abundant and less rich than those in the dead mats in summer (Borg et al., 2006). However, this seems more likely to be related to the dynamics of the dead mat assemblages, as their lowest annual diversity also occurs in summer (Gambi et al., 1995). Non-invaded dead mats were absent from the studied area, so that it has not been possible to isolate this particular effect in our analyses.

The taxonomic distinctness analysis showed that the species composition of the polychaete assemblages from Caulerpa mats was always very similar to that of Posidonia oceanica assemblages, with the only exception being those associated with samples with low or null $C$. racemosa biomass, which had a lower number of species, and thus fell outside the confidence intervals of the analyses. Altogether, this suggests that the coverage of dead seagrass meadows by the invasive $C$. racemosa provides a suitable habitat for $P$. oceanica polychaete assemblages.

The introduction of exotic species, together with habitat degradation, fragmentation and overexploitation (among other processes), may cause a reduction in species richness at large spatial scales (Rosenzweig, 2001), in association with a local modification of the overall biodiversity of each recipient benthic community. However, the effects may either be negative (Galil and Zenetos, 2002; Zenetos et al., 2003; Streftaris and Zenetos, 2006) or positive (Viejo, 1999; Crooks, 2002; Buschbaum et al., 2006), with the enhanced diversity of the invaded communities being mainly due to the 
increased habitat complexity. In fact, recent colonisations by exotic plants, animals and microbes have been reported to increase species richness locally (Rosenzweig, 2001; Sax and Gaines, 2003). Previous studies on rocky bottoms invaded by $C$. racemosa showed that the invasion mainly caused habitat modifications, and this altered the amphipod assemblage (Vazquez-Luis et al., 2008). In the case of the introduction of Caulerpa racemosa in the Balearic Islands, the analysis of the polychaete assemblages does not reveal a negative effect, as their overall species composition is coincident with that of the typical $P$. oceanica assemblages, and can be considered as locally positive, taking into account that the invaded mats also have the highest polychaete abundances. Our data supports that the introduction of exotic species may have diverse impacts at both local and temporal scales. Thus, we agree with Buschbaum et al. (2006) in that the effects of an invasion cannot be generalised, as each invasive event requires an independent study.

In summary, the invasive colonisation of Posidonia oceanica meadows by Caulerpa racemosa induces changes in the structure and functioning of the associated polychaete assemblages, both at the spatial and temporal scales. Our results demonstrate that the species composition was similar in living and dead (i.e. invaded) Posidonia meadows, with only a few characteristic species being replaced. In turn, the assemblages showed clear seasonal differences in abundance, mainly because the invasive $C$. racemosa generated a complex stolon/frond network which represents a new, suitable habitat for polychaetes. In fact, not only is the microhabitat availability enhanced, but the Caulerpa network also constitutes an effective barrier against fish predators (Longepierre et al., 2005). In the Balearic Islands, however, this is only valid for the warm period, when $C$. racemosa has significant biomasses.

In spite of the structural and seasonal changes, our results also show that it is of interest to study and assess functional aspects (e.g. bottom up and cascade effects, trophic web shifts) of the polychaete assemblages affected by the invasion, as well as their relationships with the entire benthic community.

\section{ACKNOWLEDGEMENTS}

This research was funded by the Science and Technology Ministry (Plan Nacional I+D (REN200200701/MAR)). The first author was funded by a postgraduate research grant I3P FSE. We are most grateful to J. Terrados and N. Marbà for their help during sample collection and Caulerpa mat characterisation. We also thank A. Sureda and I. Moreno for their insightful comments on the manuscript.

\section{REFERENCES}

Amade, P. and R. Lemee. - 1998. Chemical defence of the Mediterranean alga Caulerpa taxifolia: variations in caulerpenyne production. Aquat. Toxicol. 43: 287-300.

Antoniadou, C. and C. Chintiroglou. - 2006. Trophic relationships of polychaetes associated with different algal growth forms. Helgoland Mar. Res., 60: 39-49.

Antoniadou, C. and C. Chintiroglou. - 2007. Zoobenthos associated with the invasive red alga Womersleyella setacea (Rhodomelacea) in the northern Aegean Sea. J. Mar. Biol. Assoc. the U. K., 87: 629-641.

Argyrou, M., A. Demetropoulos and M. Hadjichristophorou. 1999. Expansion of the macroalga Caulerpa racemosa and changes in softbottom macrofaunal assemblages in Moni Bay, Cyprus. Oceanol. Acta, 22: 517-528.

Balata, D., L. Piazzi and F. Cinelli. - 2004. A comparison among assemblages in areas invaded by Caulerpa taxifolia and $C$. racemosa on a subtidal Mediterranean rocky bottom. Mar. Ecol. P.S.Z.N.I, 25: 1-13.

Ballesteros, M., J. Castelló, M. Gallés and R. Sarda. - 1987. Invertebrados alguícolas marinos de las Islas Pitiusas. Consell Insular d'Eivissa i Formentera, Conselleria d'Ecologia i Medi Ambient. Ciutat d'Eivissa.

Bax, N., A. Williamson, M. Aguero, E. Gonzalez and W. Geeves. - 2003. Marine invasive alien species: a threat to global biodiversity. Mar. Policy, 27: 313-323.

Bellan-Santini, D., P.M. Arnaud, G. Bellan and M. Verlaque. 1996. The influence of the introduced tropical alga Caulerpa taxifolia, on the biodiversity of the Mediterranean marine biota. J. Mar. Biol. Assoc. the U. K., 76: 235-237.

Borg, J.A., A.A. Rowden, M.J. Attrill, P.J. Schembri and M.B. Jones. - 2006. Wanted dead or alive: high diversity of macroinvertebrates associated with living and 'dead' Posidonia oceanica matte. Mar. Biol., 149: 667-677.

Boudouresque, C.F., R. Lemee, X. Mari and A. Meinesz. - 1996. The invasive alga Caulerpa taxifolia is not a suitable diet for the sea urchin Paracentrotus lividus. Aquat. Bot., 53: 245-250.

Boudouresque, C.F. and M. Verlaque. - 2002. Biological pollution in the Mediterranean Sea: invasive versus introduced macrophytes. Mar. Pollut. Bull., 44: 32-38.

Box, A. - 2008. Ecología de caulerpales: fauna y biomarcadores. PhD. thesis. Balearic Islands Univ., Spain.

Brito, M.C., D. Martin and J. Nunez. - 2005. Polychaetes associated to a Cymodocea nodosa meadow in the Canary Islands: assemblage structure, temporal variability and vertical distribution compared to other Mediterranean seagrass meadows. Mar. Biol., 146: 467-481.

Buia, M.C., M.C. Gambi, A. Terlizzi and L. Mazzella. -2001. Colonization of Caulerpa racemosa along the southern italian coast: I.Distribution, phenological variability and ecological role. In: V. Gravez, S. Ruitton, C.F. Boudouresque, L. Le Direac'h, A. Meinesz and S. G. (eds.). Fourth International Workshop on Caulerpa taxifolia, pp 352-360. GIS Posidonie, France.

Buschbaum, C., A.S. Chapman and B. Saier. - 2006. How an introduced seaweed can affect epibiota diversity in different coastal systems. Mar. Biol., 148: 743-754.

Ceccherelli, G. and N. Sechi. - 2002. Nutrient availability in the sediment and the reciprocal effects between the native seagrass Cymodocea nodosa and the introduced rhizophytic alga Caulerpa taxifolia. Hydrobiologia, 474: 57-66.

Ceccherelli, G., L. Piazzi and F. Cinelli. - 2000. Response of the non-indigenous Caulerpa racemosa (Forsskal) J-Agardh to the native seagrass Posidonia oceanica (L.) Delile: effect of density of shoots and orientation of edges of meadows. J. Exp. Mar. Biol. Ecol., 243: 227-240.

Ceccherelli, G., L. Piazzi and D. Balata. - 2002. Spread of intro- 
duced Caulerpa species in macroalgal habitats. J. Exp. Mar. Biol. Ecol., 280: 1-11.

Clarke, K.R. and R.M. Warwick. - 2001. A further biodiversity index applicable to species lists: variation in taxonomic distinctness. Mar. Ecol.-Prog. Ser., 216: 265-278.

Crooks, J.A. - 2002. Characterizing ecosystem-level consequences of biological invasions: the role of ecosystem engineers. Oikos, 97: $153-166$

Der Hartog, C. - 1994. Suddocation of a littoral Zostera bed by Enteromorpha radiata. Aquat. Bot., 47: 21-28.

Fauchald, K. and P. Jumars. - 1979. The diet of worms: a study of Polychaeta feeding guilds. Oceanogr. Mar. Biol., 17: 193-284.

Galil, B.S. and A. Zenetos. - 2002. A sea change -exotics in the Eastern Mediterranean Sea. In: E. Leppäkoski, S. Gollasch and S. Olenin (eds.), Invasive Aquatic Species in Europe, Distribution, Impacts and Management, pp 325-340. Kluwer Academic Publishers, Dordrecht, Boston, London.

Gambi, M.C., A. Giangrande, M. Martinelli and L.A. Chessa. 1995. Polychaetes of a Posidonia oceanica bed off Sardinia (Italy) - Spatiotemporal distribution and feeding guild analysis. Sci. Mar., 59: 129-141.

Gambi, M.C., G. Conti and C.S. Bremec. - 1998. Polychaete distribution, diversity and seasonality related to seagrass cover in shallow soft bottoms of the Tyrrhenian Sea (Italy). Sci. Mar., 62: $1-17$

Gambi, M.C., B.I. Van Tussenbroek and A. Brearley. - 2003. Mesofaunal borers in seagrasses: world-wide occurrence and a new record of boring polychaetes in the Mexican Caribbean. Aquat. Bot., 76: 65-77.

Gambi, M.C., B. Trani and M.C. Buia. - 2005. Taxonomic diversity and distribution of polychaete and isopod borers on the sheaths of the seagrass Posidonia oceanica: analysis at regional scale along the coast off Sardinia (Italy). Ital. J. Zool., 72: 141-151.

Givernaud, T.J., J. Cosson and A. Givernaud-Mouradi. - 1991. Etudes des populations de Sargassum muticum sur les cores de Basse, Normandies (France). In: M. Elliott and J.P. Ducrotoy (eds.).19th Symposium Estuarines and Coasts: Spatial and Temporal Intercomparison, pp 129-132. International Symposium Series.

Gollasch, S. - 2006. Overview on introduced aquatic species in European navigational and adjacent waters. Hegoland Mar. Res. 60: 84-89.

Jung, V., T. Thibaut, A. Meinesz and G. Pohnert. - 2002. Comparison of the wound-activated transformation of caulerpenyne by invasive and noninvasive Caulerpa species of the Mediterranean. J. Chem. Ecol., 28: 2091-2105.

Klein, J. and M. Verlaque. -2008. The Caulerpa racemosa invasion A critical review. Mar. Pollut. Bull., 56: 205-225.

Levi, F. and P. Francour. - 2004. Behavioural response of Mullus surmuletus to habitat modification by the invasive macroalga Caulerpa taxifolia. J. Fish Biol., 64: 55-64.

Longepierre, S., A. Robert, F. Levi and P. Francour. - 2005. How an invasive alga species (Caulerpa taxifolia) induces changes in foraging strategies of the benthivorous fish Mullus surmuletus in coastal Mediterranean ecosystems. Biodivers. Conserv., 14: 365-376

Mack, R.N., D. Simberloff, W.M. Lonsdale, H. Evans, M. Clout and F.A. Bazzaz. - 2000. Biotic invasions: causes, epidemiology, global consequences, and control. Ecol. Applications, 10: 689-710.

Martin, D., S. Pinedo and R. Sarda. - 2000. Distribution patterns and trophic structure of soft-bottom Polychaeta assemblages in north-western Mediterranean shallow-water bay. Ophelia, 53: $1-17$.

Meinesz, A. - 2004. Caulerpa taxifolia continues its invasion. Biofutur, 244: 41-46.

Meinesz, A., T. Belsher, T. Thibaut, B. Antolic, K.B. Mustapha, C.F. Boudouresque, D. Chiaverini, F. Cinelli, J.M. Cottalorda, A.S. Djellouli, A. El Abed, C. Orestano, A.M. Grau, L. Ivesa, I. Vaugelas, N. Zavodnik and A. Zuljevic. - 2001. The introduced green alga Caulerpa taxifolia continues to spread in Mediterranean. Biol. Inv., 3: 201-210.

Molenaar, H., A. Meinesz, and T. Thiebaut. - 2009. Alterations of the structure of Posidonia oceanica beds due to the introduced alga Caulerpa taxifolia. Sci. Mar., 73(2): 329-335.

Montefalcone, M., C. Morri, A. Peirano, G. Albertelli and C.N. Bianchi. - 2007. Substitution and phase shift within the Posidonia oceanica seagrass meadows of NW Mediterranean Sea. Estuar.
Coast. Shelf Sci. 75: 63-71.

Pandolfo, A. and R. Chemello. - 1995. Prime nota sulla malacofauna associata a Caulerpa racemosa nella Baia di Santa Panagia (Sicilia orientale). Biol. Mar. Mediterr., 2: 649-651.

Parent-Massin, D., V. Fournier, P. Amade, R. Lemee, M. DurandClement, C. Delescluse and D. Pesando. - 1996. Evaluation of the toxicological risk to humans of caulerpenyne using human hematopoietic progenitors, melanocytes, and keratinocytes in culture. J. Toxicol Environ. Health, 47: 47-59.

Pesando, D., P. Huitorel, V. Dolcini, P. Amade and J.P. Girard. - 1998. Caulerpenyne interferes with microtubule-dependent events during the first mitotic cycle of sea urchin eggs. Eur. $J$. Cell Biol., 77: 19-26.

Piazzi, L. and F. Cinelli. - 1999. Development and seasonal dynamics of a population of the tropical alga Caulerpa racemosa (Forsskal) J. Agardh in the Mediterranean. Cryptogamie Algol., 20: 295-300.

Piazzi, L. and F. Cinelli. - 2000. Effects of the spread of the introduced Rhodophyceae Acrothamnion preissii and Womersleyella setacea on the macroalgal community of Posidonia oceanica rhizomes in the western Mediterranean sea. Cryptogamie Algol., 21: 291-300.

Raniello, R., E. Mollo, M. Lorenti, M. Gavagnin and M.C. Buia. - 2007. Phytotoxic activity of caulerpenyne from the Mediterranean invasive variety of Caulerpa racemosa: a potential allelochemical. Biol. Inv., 9: 361-368.

Rosenzweig, M.L. - 2001. The four questions: What does the introduction of exotic species do to diversity? Evol. Ecol. Res., 3: $361-367$

Sakai, A.K., F.W. Allendorf, J.S. Holt, D.M. Lodge, J. Molofsky, K.A. With, S. Baugman, R.J. Cabin, J.E. Cohen, N.C. Ellstrand, D.E. McCauley, O. O'Neil, I.M. Parker, J.N. Thompson and S.G. Weller. - 2001. The population biology of invasive species. Ann. Rev. Ecol. Syst., 32: 305-332.

Sanchez-Moyano, J.E., F.J. Estacio, E.M. Garcia-Adiego and J.C. Garcia-Gomez. - 2001. Effect of the vegetative cycle of Caulerpa prolifera on the spatio-temporal variation of invertebrate macrofauna. Aquat. Bot., 70: 163-174.

Sax, D.F. and S.D. Gaines. - 2003. Species diversity: from global decreases to local increases. Trends Ecol. Evol., 18: 561-566.

Smith, S.D. - 2008. Interpreting molluscan death assemblages on rocky shores: Are they representative of the regional fauna? $J$. Exp. Mar. Biol. Ecol., 366: 151-159.

Streftaris, N. and A. Zenetos. - 2006. Alien marine species in the Mediterranean - the 100 'Worst Invasives' and their impact. Medit. Mar. Sci., 7(1): 87-118.

Sureda, A., A. Box, M. Ensenat, E. Alou, P. Tauler, S. Deudero and A. Pons. - 2006. Enzymatic antioxidant response of a labrid fish (Coris julis) liver to environmental caulerpenyne. Comp. Biochem. Physiol. C, 144: 191-196.

Sureda, A., A. Box, S. Deudero and A. Pons. - 2008. Reciprocal effects of caulerpenyne and intense herbivorism on the antioxidant response of Bittium reticulatum and Caulerpa taxifolia. Ecotoxicol. Environ. Saf. in press: doi:10.1016/j.ecoenv.2007.12.007.

Vazquez-Luis, M., P. Sanchez-Jerez and J.T. Bayle-Sempere. 2008. Changes in amphipod (Crustacea) assemblages associated with shallow-water algal habitats invaded by Caulerpa racemosa var. cylindracea in the western Mediterranean Sea. Mar. Environ. Res., 65: 416-426.

Viejo, R.M. - 1999. Mobile epifauna inhabiting the invasive Sargassum muticum and two local seaweeds in northern Spain. Aquat. Bot., 64: 131-149.

Warwick, R.M. and J. Light. - 2002. Death assemblages of molluscs on St Martin's Flats, Isles of Scilly: a surrogate for regional biodiversity? Biodivers. Conserv. 11: 99-112.

Wentworth, W. - 1972. A scale of grade and class terms for clastic sediments. J. Geol., 30: 377-392.

Zenetos, A., S. Gofas, G.F. Russo and J. Templado. - 2003. CIESM Atlas of Exotic Species in the Mediterranean, Volume 3: Mollusc. CIESM Publishers, Monaco.

Zuljevic, A., B. Antolic and V. Onofri. - 2003. First record of Caulerpa racemosa (Caulerpales : Chlorophyta) in the Adriatic Sea. J. Mar. Biol. Assoc. U.K., 83: 711-712.

Scient. ed.: J.S. Troncoso.

Received March 9, 2009. Accepted July 23, 2009.

Published online March 8, 2010. 